\title{
STUDI MORFOMETRIK DAN MERISTIK IKAN KURISI (Nemipterus Sp) YANG DIDARATKAN DI PELABUHAN PERIKANAN NUSANTARA (PPN) SUNGAILIAT KABUPATEN BANGKA
}

\section{THE STUDY OF MORFOMETRIC AND MERISTIC CURRY FISH (Nemipterus sp) LANDED IN NUSANTARA FISHERY HARBOUR OF SUNGAILIAT, BANGKA REGENCY}

\author{
Andi Gustomi* dan Sri Dewi Dinata Putri \\ Program Studi Manajemen Sumberdaya Perairan, Fakultas Pertanian Perikanan dan Biologi, \\ Universitas Bangka Belitung \\ Kampus Terpadu UBB, Gedung Teladan, Desa Balunijuk, Bangka, \\ Kepulauan Bangka Belitung, 33172 Indonesia \\ Email: andigustomi@gmail.com
}

\begin{abstract}
ABSTRAK
Ikan Kurisi (Nemipterus $s p$ ) merupakan salah satu ikan yang menjadi komoditas utama dari bermacam ikan yang didaratkan di PPN Sungailiat Kabupaten Bangka. Ikan Kurisi dimanfaatkan sebagai Isumber bahan pangan protein hewani. Penelitian ini bertujuan untuk mengidentifikasi karakteristik morfometrik dan meristik ikan kurisi yang didaratkan di PPN Sungailiat Kabupaten Bangka. Penelitian ini dilaksanakan pada bulan Desember Tahun 2018 hingga Bulan Januari 2019 di PPN Sungailiat Kabupaten Bangka. Pengambilan data menggunakan metode random sampling sebanyak 21 ekor ikan kurisi. Berdasarkan 23 karakter morfometrik dan 9 karakter meristik yang di analisis. Karakter morfometrik ikan kurisi menunjukkan bahwa Panjang Total 16,5 cm hingga $21 \mathrm{~cm}$ dengan rerata $18,93 \mathrm{~cm}$. Sedangkan karakter meristik ikan kurisi menunjukkan bahwa ikan ini memiliki rumus Jari-jari Sirip Punggung (D.XI-D.XII.8), Sirip Dubur (A.III.11-A.III.14), Pectoral rays (P.12), Ventral rays (V.9-V.10) dan Caudal rays (C.40C.43). Berdasarkan hasil identifikasi ikan kurisi termasuk ke dalam jenis dari genus Nemipterus dengan spesies Nemipterus japonicus .
\end{abstract}

Kata kunci :Ikan Kurisi (Nemipterus sp), Morfometrik, Meristik, PPN Sungailiat Bangka

\begin{abstract}
Curry fish (Nemipterus $s p$ ) is one of the fish which is the main commodity of various fish Landed In Nusantara Fishery Harbour Of Sungailiat, Bangka Regency. This Curry fish is used as a source of food from animal. This research aimed to identified the characteristics Morfometric and Meristic Curry Fish (Nemipterus sp) Landed In Nusantara Fishery Harbour Of Sungailiat, Bangka Regency. The research was held on December 2018 to January 2019 in Nusantara Fishery Harbour (PPN) Of Sungailiat, Bangka Regency. The data was taken using random sampling method. This research takes 23 morfometric characters and 9 meristic characters to analyze. The morphometric character of Curry Fish showed that total length is $16,5 \mathrm{~cm}$ to $21 \mathrm{~cm}$ with average $18,93 \mathrm{~cm}$. The character of merictic of Curry Fish has the formula of Dorsal rays (D.XI-D.XII.8), Anal rays (A.III.11-A.III.14), Sirip Dada (P..12), Sirip Perut (V.9V.10) dan Caudal rays (C.40-C.43). Based on identification Curry Fish is from genus of Nemipterus with species Nemipterus japonicus.
\end{abstract}

Keywords:Ikan Kurisi (Nemipterus sp), Morphometric, Meristic, PPN Sungailiat Bangka

\section{PENDAHULUAN}

Pelabuhan Perikanan Nusantara (PPN) Sungailiat merupakan salah satu dari sekian Pelabuhan Perikanan di Indonesia, dengan letak geografis $01^{\circ} 51^{\prime} 56^{\prime \prime}$ LS $-106^{\circ} 07^{\prime} 20^{\prime \prime}$ BT. Keberadaan Pelabuhan Perikanan Nusantara (PPN) Sungailiat sebagai pembangunan perikanan daerah, antara lain sebagai penunjang proses moderensasi unit 
penangkapan ikan tradisional secara bertahap, dan perbaikan usaha perikanan tangkap dalam pemanfaatan sumberdaya ikan secara optimal dan berkesinambungan. Hal ini dimungkinkan karena pelabuhan perikanan dilengkapi dengan fasilitas yang dapat memberikan kemudahan bagi Nelayan baik persipan operasional, pendaratan dan pemasaran ikan hasil tangkapan (KKP, 2015).

Salah satu hasil tangkapan yang didaratkan pada Pelabuhan Perikanan Nusantara (PPN) Sungailiat ialah Ikan Kurisi (Nemipterus sp). Pada daerah Kepulauan Bangka Belitung, Ikan Kurisi dimanfaatkan sebagai sumber bahan pangan protein hewani, keunikan Ikan Kurisi ini sendiri ialah memiliki bentuk tubuh agak bulat memanjang, tertutup sisik yang dilengkapi dengan sisik yang mudah tanggal atau lepas. Kebanyakan masyarakat Bangka mengkonsumsinya dengan cara dibakar, hal ini dikarenakan sisik pada ikan ini yang tebal, namun memiliki ciri khas daging yang lembut dan enak dengan kisaran harga antara $\mathrm{Rp}$. 22.000,- sampai Rp. 30.000,- /Kg tergantung besar kecil ukuran. Tingginya permintaan dan produksi ikan Kurisi di Kabupaten Bangka membuat penting untuk dilakukan kajian identifikasi agar pengelolaan sumberdaya ikan Kurisi kedepan dapat dilakukan dengan tepat. Dalam pengelolaan sumberdaya perikanan kajian minimum yang harus tepat dilakukan adalah identifikasi jenis ikan. Identifikasi jenis ikan dilakukan untuk memastikan penamaan jenis-jenis ikan secara ilmiah melalui analisis taksonomi menggunakan parameter morfometrik dan meristik. Beberapa kajian ikan Kurisi (Nemipterus $s p$ ) yang pernah dilakukan di PPN Sungailiat yaitu kajian reproduksi (Persada et al., 2016), potensi lestari dan musim penangkapan (Juandi et al., 2016) sedangkan kajian terkait karakteristik morfometrik dan meristik ikan kurisi di PPN Sungailiat belum pernah ditemukan, sehingga menjadi penting untuk dikaji sebelum dilakukan pengelolaan kearah yang lebih penting.

Belum adanya kajian tentang jenisjenis ikan Kurisi di Kabupaten Bangka membuat tidak tersedianya data tentang penamaan ikan kurisi, sehingga menjadi penting untuk dikaji agar diketahui jenis dari ikan kurisi tersebut, oleh karena itu perlu adanya kajian identifikasi jenis ikan melalui parameter morfometrik dan meristik Ikan Kurisi (Nemipterus $s p$ ) yang didaratkan di PPN Sungailiat Kabupaten Bangka. Tujuan dari penelitian ini adalah untuk mengungkap jenis dari ikan Kurisi yang didaratkan di PPN Sungailiat Kabupaten Bangka melalui parameter meristik dan morfometrik ikan.

\section{METODE PENELITIAN}

Penelitian dilakukan pada Bulan Desember Tahun 2018 hingga Bulan Januari 2019. Penelitian ini dilakukan melalui dua tahap, Tahap pertama, dilakukan pengambilan sampel di Pelabuhan Perikanan Nusantara (PPN) Sungailiat Kabupaten Bangka secara random sampling dari beberapa nelayan. Ikan yang diambil kemudian dimasukkan kedalam plastik sampel dan diberikan larutan formalin 4\% agar ikan tidak busuk. Total ikan yang diambil dari nelayan keseluruhan berjumlah 21 ekor. Tahapan Kedua, yang dilakukan adalah pengamatan dan pengukuran karakter Morfometrik dan Meristik Ikan yang dilakukan di Laboratorium Perikanan Fakultas Pertanian, Perikanan dan Biologi Universitas Bangka Belitung mengacu pada Affandi (1992).

\section{Analisis Data Identifikasi Morfometrik}

Identifikasi morfometrik merupakan kajian yang bersangkutan dengan variasi dan perubahan bentuk (ukuran dan bentuk) dari organisme, meliputi pengukuran panjang dan analisis kerangka secara kuantitatif. Cara pengukuran Morfometrik adalah disiapkan Bahan sampel ikan yang akan diidentifikasi, kemudian ukur panjang tubuh ikan serta beberapa karakter morfometrik lainnya.

\section{Analisis Data Identifikasi Meristik}

Identifikasi Meristik merupakan perhitungan bagian tertentu pada tubuh ikan, misalnya meliputi jumlah sisik pada gurat sisi (Linea lateralis), jumlah jari- jari keras dan lemah pada sirip ikan, dan jumlah sisik melintang tubuh. Cara pengukuran Meristik adalah yang pertama disiapkan Bahan sampel ikan yang akan diidentifikasi, Kemudian sampel diukur panjang setiap sirip, jumlah jari-jari sirip hingga jumlah sisik pada ikan.

\section{HASIL DAN PEMBAHASAN}

\section{Karakteristik Morfometrik Ikan Kurisi}

Ikan Kurisi yang didapat dari Pelabuhan Perikanan Nusantara (PPN), Kabupaten Bangka untuk diidentifikasi karakter morfologi terkait pengukuran morfometrik (23 karakter) dan perhitungan meristik (9 karakter). Berdasarkan hasil pengukuran morfometrik pada Tabel 1 menyajikan 


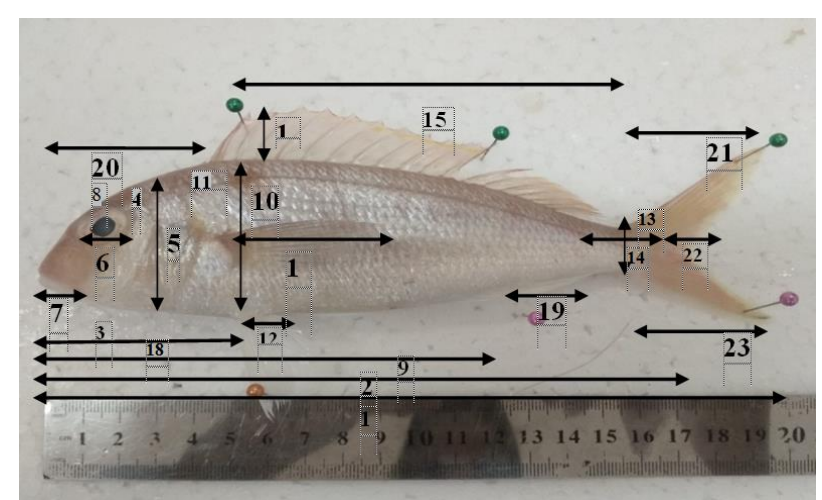

Gambar 1. Skema Pengukuran Morfometrik Ikan Kurisi (Modifikasi dari Affandi, 1992).

Keterangan:

1. panjang total $(T L) ; 2$. panjang standar $(\mathrm{SL})$; 3. panjang kepala $(\mathrm{HL})$; 4. lebar kepala (HW); 5. tinggi kepala (HD); 6. diameter mata (ED); 7. panjang moncong (SNL); 8 . jarak antar mata (IW); 9. panjang sebelum sirip dubur (PAL); 10. tinggi badan (BD); 11 . lebar badan (BW); 12. panjang sirip perut (PVL); 13. tinggi pangkal ekor (CPD); 14. panjang pangkal ekor (CPL);15. panjang dasar sirip punggung (DBL); 16. tinggi sirip punggung (DFH); 17 . panjang sirip dada $(P C L)$; 18. panjng sebelum sirip perut $(P P L)$; 19. panjang dasar sirip dubur $(A B L) ; 20$. panjang sebelum sirip punggung (PDL); 21. panjang sirip ekor bagian atas (LUCL); 22. Panjang sirip ekor bagian tengah (LMCL); 23. panjang sirip ekor bagian bawah (LCLL)

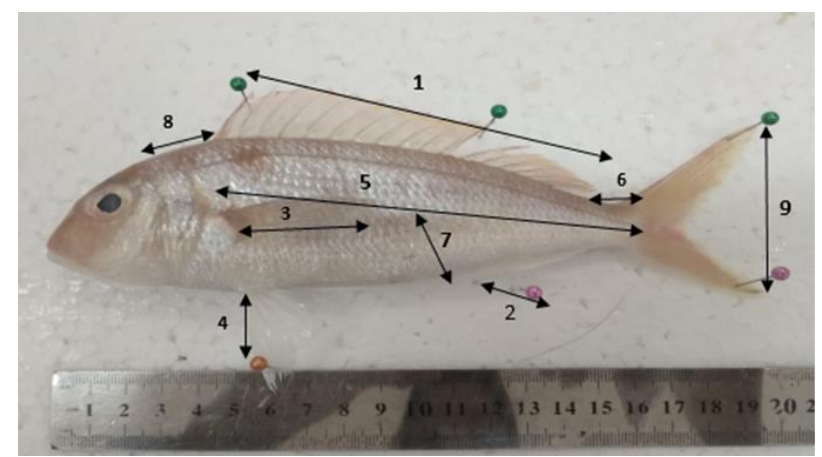

Gambar 2. Skema Pengukuran Meristik Ikan Kurisi (Modifikasi dari Affandi, 1992).

Keterangan:

1. jari-jari sirip punggung (Dorsal rays); 2. jari-jari sirip dubur (Anal rays); 3. jari-jari sirip dada (Pectoral rays); 4. Sirip Perut (Ventral rays); 5. sisik pada garis lateral atau gurat sisi (Linea lateralis); 6. Sisik pada batang ekor (Caudal peduncle scale) 7. sisik melintang tubuh (Transverse scale); 8. Sisik Sebelum sirip punggung (Pedorsal scale); 9. jari- jari sirip ekor (Caudalrays). kisaran hasil pengukuran karakter morfometrik yang menjadi sampel penelitian. Menurut Sulistyawati (2011) Ikan Kurisi memiliki bentuk mulut yang letaknya agak ke bawah dan adanya sungut yang terletak didagunya yang digunakan untuk meraba dalam usaha pencarian makanan, memiliki badan langsing dan padat. Ikan ini memiliki warna sangat bervasiasi, seperti kemerahmerahan, merah kekuningan ataupun kehijau-hijauan. Sirip dorsal berwarna merah, dengan garis tepi berwarna kuning yang luas sepanjang dasar sirip dorsal.

Panjang total (TL) Ikan Kurisi yang didaratkan di Pelabuhan Perikanan Nusantara (PPN) Sungailiat Kabupaten Bangka berkisar antara 16,5-21 cm dengan rerata $18,93 \mathrm{~cm}$. Akan tetapi berdasarkan Oktaviyani, et al (2016) bahwa Panjang Total Ikan Kurisi yang di daratkan di Perairan Teluk Banten berkisar antara 9,8 cm $-21,1 \mathrm{~cm}$. Pada penelitian ini, tidak dibedakan antara ikan jantan dan betina sehingga rerata yang dipaparkan dalam Tabel 1 merupakan kisaran dan rerata karakter morfometrik semua sampel tanpa membedakan betina dan jantan.

Panjang baku atau Standard length (SL) merupakan panjang tubuh dari bagian mulut paling anterior sampai pangkal batang ekor (caudal penducle).Panjang standar Ikan Kurisi yang didaratkan di Pelabuhan Perikanan Nusantara ( PPN) Sungailiat berdasarkan Tabel 1 memiliki kisaran 13,5 - 16,4 cm dengan rerata $14,975 \mathrm{~cm}$. Selisish rerata panjang total ( $T L$ ) dengan panjang standar (SL) ialah $3,96 \mathrm{~cm}$. Selisih ini menunjukkan panjang bagian tubuh Ikan Kurisi dari pangkal ekor hingga ujung ekor. Tabel 1 menunjukkan bahwa panjang Pangkal Ekor (CPL) memiliki kisaran $1-2,1 \mathrm{~cm}$ dengan rerata $1,695 \mathrm{~cm}$. Panjang sirip ekor bagian atas (LUCL) memiliki kisaran 3,2-5,3 cm dengan rerata $4,175 \mathrm{~cm}$, dan Panjang sirip ekor bagian bawah (LCLL) memiliki kisaran 3$5 \mathrm{~cm}$ dengan rerata $3,73 \mathrm{~cm}$.

Perbedaan rerata panjang standar dan panjang ekor ikan kurisi yang didaratkan di Pelabuhan Perikanan Nusantara (PPN) Sungailiat memiliki perbandingan 2,6:1 menunjukkan bahwa panjang standar atau panjang dari ujung moncong ikan hingga ke pangkal ekor memiliki ukuran 2,6 kali lebih besar dibandingkan bagian ekor ikan kurisi yang didaratkan di PPN Sungailiat Kabupaten Bangka. Nilai perbandingan didapatkan dari nilai rerata panjang standar dan panjang keseluruhan ekor yang mencakup pangkal ekor dan panjang sirip ekor. 
Tinggi badan (BD) ikan Kurisi yang didaratkan di Pelabuhan Perikanan Nusantara (PPN) Sungailiat Kabupaten Bangka memiliki kisaran 3,1 - $5 \mathrm{~cm}$ dengan rerata $4,045 \mathrm{~cm}$. Tubuh ikan terdiri dari tiga bagian yaitu Caput (bagian kepala), Truncus (bagian badan), dan Caudal (bagian ekor). Bagian truncus terdiri dari berbagai organ termasuk sirip (Bond, 1979). Sirip ikan umumnya terbagi menjadi 5 yaitu sirip punggung (Pinna dorsalis), sirip perut (Pinna ventralis), sirip dada (Pinna pektoralis), Sirip ekor dan sirip dubur/anal (Pinna analis). Sebagian ikan memiliki sirip tambahan berupa adipose fin.

Parameter morfometrik yang didaratkan di Pelabuhan Perikanan (PPN) Sungailiat Kabupaten Bangka terdiri dari 5 parameter diantaranya yaitu sirip punggung (Pinna dorsalis) ,sirip perut (Pinna ventralis), sirip dada (Pinna pektoralis), sirip ekor dan sirip dubur/anal (Pinna analis). Sirip ikan dengan rerata terpanjang ialah sirip punggung (Pinna dorsalis) dengan rerata panjang dari 20 sampel yaitu $10,35 \mathrm{~cm}$ diikuti sirip dada (Pinna pektoralis) dengan rerata $3,62 \mathrm{~cm}$ sedangkan sirip terpendek ialah sirip perut (Pinna ventralis) dengan rerata sebesar 3,46 $\mathrm{cm}$.

\section{Karakteristik Meristik Ikan Kurisi}

Meristik adalah ciri yang berkaitan dengan jumlah bagian tubuh ikan, misalnya jumlah sisik pada garis rusuk, jumlah jari-jari keras dan lemah pada sirip punggung (Haryono, 2001).Parameter meristik Ikan Kurisi yang diukur ada 9 parameter yaitu jarijari sirip punggung (Dorsal rays); jari-jari sirip dubur (Anal rays); jari-jari sirip dada (Pectoral rays); Sirip Perut (Ventral rays); sisik pada garis lateral atau gurat sisi (Linea lateralis); Sisik pada batang ekor (Caudal Peduncle scale) sisik melintang tubuh (Transverse scale); Sisik Sebelum sirip punggung (Pedorsal scale); dan Jari-jari sirip ekor (Caudal rays).

Hasil pengamatan dan perhitungan secara visual tentang karakteristik meristik pada Tabel 2 didapat bahwa Ikan Kurisi memiliki jari-jari sirip punggung (Dorsal rays) sebanyak D. XI 8- D. XII 8. Artinya, ada sampel yang memiliki jari-jari sirip keras sirip punggung sebanyak $11-12$ jari-jari dan 8 jari-jari sirip lemah. Berdasarkan hasil penelitian, jari-jari sirip dubur (Anal rays) ikan Kurisi sampel ialah A.III 11-A.III 14 dan Jari-jari sirip dada (Pektoralis rays) P.12. Sisik menjadi salah satu parameter meristik

Tabel 1. Parameter Morfometrik

\begin{tabular}{|c|c|c|c|c|}
\hline No & Kode & Keterangan & Sampel Ikan $(\mathrm{cm})$ & Rerata \\
\hline 1 & TL & Panjang Total & $16,5-21$ & 18,93 \\
\hline 2 & SL & Panjang Standar & $13,5-16,4$ & 14,925 \\
\hline 3. & $\mathrm{HL}$ & Panjang Kepala & $3,8-4,9$ & 4,56 \\
\hline 4 & HW & Lebar Kepala & $1,24-1,72$ & 1,463 \\
\hline 5 & HD & Tinggi Kepala & $3,5-6$ & 4,495 \\
\hline 6 & ED & Diameter Mata & $0,96-1,8$ & 1,2165 \\
\hline 7 & SNL & Panjang Moncong & $1-2$ & 1,48 \\
\hline 8 & IW & Jarak Antar Mata & $0,9-1,18$ & 1,085 \\
\hline 9 & PAL & Panjang Sebelum Sirip Dubur & $8,2-11,5$ & 9,735 \\
\hline 10 & $\mathrm{BD}$ & Tinggi Badan & $3,1-5$ & 4,045 \\
\hline 11 & BW & Lebar Badan & $1,35-1,62$ & 1,544 \\
\hline 12 & PVL & Panjang Sirip Perut & $2,8-4$ & 3,45 \\
\hline 13 & CPD & Tinggi Pangkal Ekor & $1,1-2$ & 1,485 \\
\hline 14 & CPL & Panjang Pangkal Ekor & $1-2,1$ & 1,695 \\
\hline 15 & $\mathrm{DBL}$ & Panjang Dasar Sirip Punggung & $3-4,5$ & 10,34 \\
\hline 16 & DFH & Tinggi Sirip Punggung & $2,8-6,3$ & 1,54 \\
\hline 17 & PCL & Panjang Sirip Dada & $2,9-4,5$ & 3,57 \\
\hline 18 & PPL & Panjang Sebelum Sirip Perut & $2,8-6,3$ & 4,8578 \\
\hline 19 & $A B L$ & Panjang Dasar Sirip Dubur & $2,9-4,5$ & 3,63 \\
\hline 20 & PDL & Panjang Sebelum Sirip Punggung & $3,6-6,4$ & 4,7 \\
\hline 21 & LUCL & Panjang Sirip Ekor Bagian Atas & $3,2-5,3$ & 4,175 \\
\hline 22 & LMCL & Panjang Sirip Ekor Bagian Tengah & $0,9-2$ & 1,345 \\
\hline 23 & LCLL & Panjang Sirip Ekor Bagian Bawah & $3-5$ & 3,73 \\
\hline
\end{tabular}


Tabel 2. Parameter Meristik

\begin{tabular}{cccc}
\hline No & Kode & Keterangan & $\begin{array}{c}\text { Hasil Perhitungan Karakteristik } \\
\text { Meristik }\end{array}$ \\
\hline 1 & DR & Jari-jari Sirip Punggung & D.XI.8 - D.XII.8 \\
2 & AR & Jari-jari Sirip Dubur & A.III.11-A.III.14 \\
3 & PR & Jari-jari Sirip Dada & P.12 \\
4 & VR & Jari-jari Sirip Perut & V.9-V.10 \\
5 & CR & Jari-jari Sirip Ekor & C.40-C.43 \\
6 & LL & Sisik Garis Lateral & $12-62$ \\
7 & CPS & Sisik Batang Ekor & $16-21$ \\
8 & TS & Sisik Melintang Tubuh & $10-12$ \\
9 & PS & Sisik Sebelum Sirip Punggung & \\
\end{tabular}

dalam penelitian ini. Jumlah sisik garis lateral/gurat sisi ikan Kurisi ialah 58 - 62 sisik, sisik melintang tubuh 10-21 sisik, sisik sebelum sirip punggung 10-12 sisik dan sisik batang ekor 12-16 sisik.

Effendie (2002), menyatakan bahwa sirip pada ikan berperan dalam penentuan arah dan gerak ikan yang terdiri dari sirip punggung, sirip dada, sirip ekor, sirip dubur, dan sirip perut. Tidak semua jenis ikan memiliki secara utuh kelima sirip tersebut secara sempurna.

\section{Identifikasi Ikan Kurisi}

Menurut Astawan (2004) spesies Nemipterus $s p$ memiliki bentuk agak bulat memanjang, tertutup sisik yang mudah tanggal atau lepas kepala tanpa duri bagian depannya tidak bersisik memiliki sirip punggung D.X.9 jari-jari keras pertama dan kedua tumbuh memanjang seperti serabut. demikian juga jari-jari teratas lembaran sisip ekornya. Sirip dubur berjari-jari keras 3 dan 7 jari-jari lemah. Warna kepala dan gigi punggung kemerahan. Sirip punggung abuabu keunguan dengan warna kuning ditengahnya. Ukuran ikan kurisi dapat mencapai panjang $25 \mathrm{~cm}$, umumnya 12 hingga $18 \mathrm{~cm}$. Hal tersebut sesuai dengan Russell (1990) panjang baku maksimum ikan kurisi di Perairan Cina Selatan adalah $25 \mathrm{~cm}$.

Genus Nemipterus yang didaratkan di PPN Sungailiat memiliki karakter meristik diantaranya jari-jari sirip punggung (Dorsal rays) sebanyak D. XI 8- D. XII 8. Sedangkan menurut Astawan (2004) ikan kurisi memiliki sirip punggung berjari-jari keras 10 dan 9 jari-jari lemah.

Identifikasi ikan menggunakan kunci determinasi khusus ikan dari spesies Nemipterus $s p$ menggunakan kunci determinasi Saanin (1984). Menurut Saanin (1984) ikan dari genus ini memiliki jari-jari keras pada sirip punggung $X$ dan berjari-jari lemah 8-9 sedangkan berdasarkan hasil pengamatan ikan kurisi genus Nemipterus yang didaratkan di PPN Sungailiat memiliki jari-jari keras pada sirip punggung XI-XII dan jari-jari lemah 8 merupakan genus Nemipterusdengan Spesies Nemipterus japonicus.

Pembagian spesies lainnya ialah dilihat dari warna tubuh ikan Nemipterus japonicus kemerah mudaan dengan 11 atau 12 garis kuning di sisi dan bercak kemerahan di punggung apabila ikan memiliki tubuh kemerah mudaan dengan 6 hingga 8 garis kuning disisi dan bercak merah dibatasi warna kuning di punggung maka digolongan ke spesies Nemipterus hexodon, jika warna tubuh merah muda dengan garis kuning samar dan bintik merah di punggung digolongkan ke spesies Nemipterus marginatus. Berdasarkan pengamatan ikan kurisi menjadi sampel memiliki warna tubuh kemerah mudaan dengan 11 sampai 12 garis kuning dan terdapat bercak merah dipunggung dimasukkan ke dalam spesies Nemipterus japonicus.

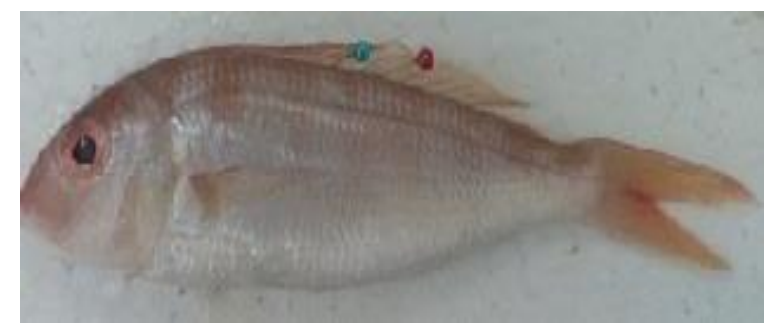

Gambar 3. Nemipterus japonicus

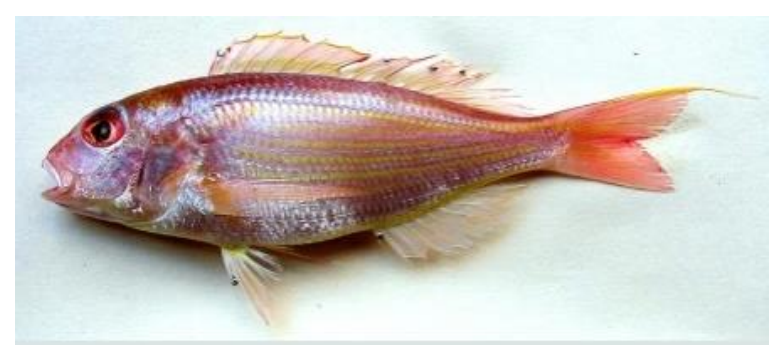

Gambar 4.Nemipterus hexodon 


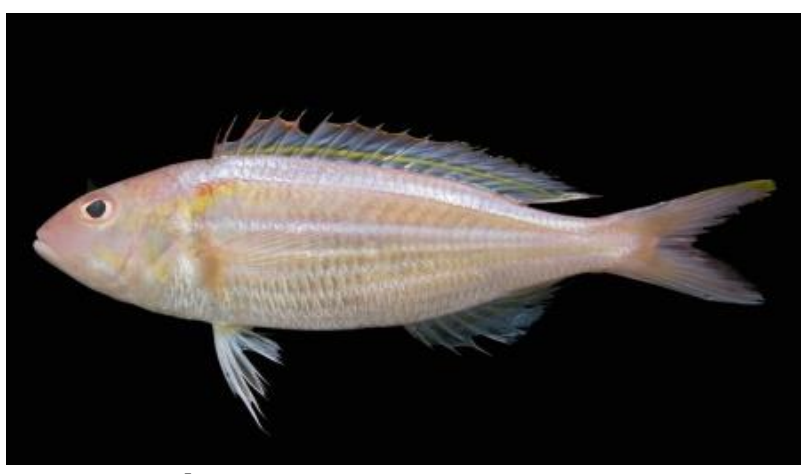

Gambar 5.Nemipterus marginatus

\section{KESIMPULAN}

Hasil penelitian menunjukkan terdapat 23 karakteristik morfometrik Ikan Kurisi dan 9 karakteristik meristik. Pada karakter morfometrik ikan yang menjadi sampel memiliki kisaran panjang total $16,5 \mathrm{~cm}$ hingga $21 \mathrm{~cm}$ dengan rerata $18,93 \mathrm{~cm}$. Sedangkan karakter meristik menunjukkan bahwa ikan Kurisi memiliki rumus jari-jari sirip yang bervariasi D. XI 8 - D. XII 8. A.III 11 - A.III 14 (Jari-jari Sirip Dubur), P.12 ( Jari-jari sirip dada), V.9- V. 10 ( Jari-jari sirip perut) dan C.40- C.43 ( Jari-jari sirip ekor) sehingga dalam identifikasi menggunakan kunci determinasi menunjukkan bahwa ikan kurisi yang diidentifikasi selama penelitian berasal dari family Nemiptridaegenus Nemipterus dengan spesies Nemipterus japonicus.

\section{REFERENSI}

Astawan, M. 2004. Ikan yang Sedap dan Bergizi. Tiga Serangkai. Solo

Bond, CE. 1979. Biology of Fishes.Saunders College Publishing. Philadelphia,

Effendie, M.I. 2002. Biologi Perikanan. Yayasan Pustaka Nusantara : Yogyakarta

Haryono. 2001. Variasi Morfologi dan Morfometrik Ikan Dokun (Puntius

\section{lateristiga) di Sumatra. Biota} VI(3):109-116.

Juandi, Utami, E., dan Adi, W. 2016. Potensi Lestari dan Musim Penangkapan Ikan Kurisi (Nemipterus sp) yang Didaratkan pada Pelabuhan Perikanan Nusantara Sungailiat. Akuatik Jurnal Sumberdaya Perairan 10(1):49-56

KKP. (2015). Laporan Tahunan Pelabuhan Perikanan Nusantara Sungailiat Tahun 2014. Sungailiat: PPN Sungailiat, Kementerian Kelautan dan Perikanan.

Oktaviyani, S., Boer, M., dan Yonvitner. 2016. Aspek Biologi Ikan Kurisi (Nemipterus japonicus) Di Perairan Teluk Banten. Bawal. 8(1):21-28.

Persada, L.G, Utami, E., dan Rosalina, D. 2016. Aspek Reproduksi Ikan Kurisi (Nemipterus Furcosus) yang Didaratkan di Pelabuhan Perikanan Nusantara Sungailiat. Akuatik Jurnal Sumberdaya Perairan 10(2):46-55

Russell, B.C. 1990. FAO Species Catalogue, Nemipterid fishes of the wold, (Threadfin breams, whiptail breams, monocle breams, dwarf monocle breams, and coral breams). Family Nemiptridae. An annotated and illustrated catalogue of nemipterid species known to date. FAO Fish. Synop Rome. 12 (125): 149

Saanin, H. 1984. Klasifikasi dan Kunci Identifikasi Ikan. Bandung (ID) :PT Cipta.

Sulistyawati, E.T. 2011. Pengelolaan Sumberdaya Ikan Kurisi (Nemipterus furcocus) Berdasarkan Model Produksi Surplus di Teluk Banten., Kabupaten Serang, Provinsi Banten. Departemen Manajemen Sumberdaya Perairan. Fakultas Perikanan dan Ilmu Kelautan. Institut Pertanian Bogor. Bogor 